\title{
THE TRANSPARENCY OF INFORMATION IN TERMS OF CRIME CLEARANCE IN BANGKALAN POLICE RESORT AREA AS A CONTROL FOR POLICE PERFORMANCE BY SOCIETY ${ }^{\Omega}$
}

\author{
Tolib Effendi \\ Faculty of Law Universitas Trunojoyo Madura \\ E-mail: te.effendi@gmail.com
}

\begin{abstract}
Transparency of information became one of the legal reform agenda within the theme of strengthtening the rule of law. Without any public transparency of information, particulary in terms of the completion of criminal cases (crime clearance) by the police, then how can the public contribute to monitor the criminal justice system. Therefore, it needs to be re-examined regarding the transparency of information about the completion of the criminal case as one of the control performance of the police by the public. This research is a descriptive - exploratory elaborated on the level of transparency of information about the crime clearance of the case in the Police Bangkalan as one of the control performance of the police by the public. The transparency of information about the number of cases solved by the Police Bangkalan certaintly can support public trust in the performance conducted by the police. This study started from the idea that one model of control that occur in Indonesia within the framework of the criminal justice system is community involvement in monitoring/ control of law enforcement.
\end{abstract}

Keywords: transparency, control, police, public.

\begin{abstract}
Abstrak
Keterbukaan informasi (transparency) menjadi salah satu agenda reformasi hukum dalam tema penguatan Negara hukum (rule of law). Tanpa adanya keterbukaan informasi publik, khususnya dalam hal penyelesaian perkara pidana oleh Kepolisian Negara Republik Indonesia, maka bagaimana masyarakat bisa turut memantau jalannya proses penyelesaian perkara. Oleh karena itu perlu diuji kembali mengenai keterbukaan informasi tentang penyelesaian perkara sebagai salah satu kontrol kinerja Kepolisian Negara Republik Indonesia oleh masyarakat. Penelitian ini merupakan penelitian deskriptif - eksploratif memaparkan tentang tingkat keterbukaan informasi tentang penyelesaian perkara di wilayah Kepolisian Resort Bangkalan sebagai salah satu kontrol kinerja Kepolisian Negara Republik Indonesia oleh masyarakat. Adanya keterbukaan informasi tentang jumlah perkara yang diselesaikan oleh Kepolisian resor Bangkalan tentunya dapat menunjang kepercayaan masyarakat atas kinerja yang dilakukan oleh kepolisian. Penelitian ini berangkat dari pemikiran, bahwa salah satu model pengawasan yang ada di Indonesia dalam kerangka sistem peradilan pidana adalah keterlibatan masyarakat dalam melakukan pengawasan/ kontrol kinerja penegak hukumnya.
\end{abstract}

Kata kunci: transparansi, pengawasan, polisi, masyarakat

\section{Introduction}

There are 12 characteristics in modern constitutional state which support the founding of rule of law pillars, they are: the supremacy of law; equality in law; the principle of legality; limitation of power; independent supporting organs; independent and impartial judiciary; State Adminisration Court; The Constitutional Court; The protection of Human Rights; democratic; its func-tion as a tool to actualize the aim of state; and transparency and social control. ${ }^{1}$

Transparency of information became one of the legal reform agenda within the theme of

$\Omega$ Research funded by Program Hibah Penelitian Internal Dosen Faculty of Law, Universitas Trunojoyo Madura in 2015.

1 Ramiyanto, "Sah atau Tidaknya Penetapan Tersangka sebagai Objek Gugatan Praperadilan: Kajian Putusan Nomor 04/Pid.Prap/2015/PN.Jkt.Sel”, Jurnal Yudisial, Vol 8 No. 2 August 2015, Jakarta: Komisi Yudisial, 2015, page 172 . 
strengthtening the rule of law. This is because of the openness is very related with two important issues, Human Rights; and corruption prevention and eradication. Transparency of information can also optimizing society participation to encourage the implementation of good governance. ${ }^{2}$ Melvin I. Urofsky said that government should be opened, which means the idea and the decision should be opened for public testing carefully. ${ }^{3}$

Transparency of public information regulated in Law 14 of 2008 about The Transparency of Public Information. Indonesia become the fifth country in Asia and the $76^{\text {th }}$ country which is formally adopt the transparency of information principles, eventough it is late but at least there has been an effort towards it. It must be admitted to actualize that urge needs readiness especially for state administrators, to be able to provide wide access of information to community of information users. The demands of state administrators readiness and government is reinforced with the support comes from inside and also outside. ${ }^{4}$

The formation of Public Information Transparency Law can not be separated from the public supports who want The Law with reasons, such as: first, strong pressure comes from public against corruption eradication, Collusion and Nepotism; second, to create public participation in the development process; third, to have a quality press; fourth, strong public pressure to reveal against Human Rights in the past; fifth, the protection of consumers; and sixth, public pressure towards the management resources based on the carrying capacity of an ecosystem and the society interests. ${ }^{5}$

2 Choky Ramadhan and Aulia Ali Reza, 2015, Keterbukaan Informasi Kejaksaan: Implementasi dan Permasalahan, in Bunga Rampai Kejaksaan Republik Indonesia, Jakarta: Badan Penerbit Faculty of Law UI, page 134.

3 Eko Harry Susanto, "Undang-Undang Keterbukaan Informasi Publik dan Penyelenggaraan Pemerintahan", Jurnal Komunikator, Vol. 5 No. 3, 2013, Yogyakarta: Universitas Muhammadiyah Yogyakarta, page 126.

4 Sumrahyadi and Erwan Baharudin, "Antropologi Hukum dalam Implikasi Undang-Undang Keterbukaan Informasi Publik", Jurnal Lex Jurnalica (Jurnal of Law), Vol. 6 No. 2 April 2009, Jakarta: Universitas Esa Unggul, page 125.

5 Fauzin, "Keberpihakan Pengaturan Hak Atas Informasi Publik dalam Undang-Undang Keterbukaan Informasi
Law of The Transparency of Public Information is adressed to allow society to access every public information which is open from public body. According to Article 1 point 3 Law of The Transparency of Public Information, Public Body is the executive, legislative, judicial, and other body which has function and main task related with the administration of the state, partly or entirely funded from State Budget and/or Regional Budget, or non-govermental organization as long as partly or entirely the fund comes from State Budget and/or Regional Budget, public contribution, and/or overseas. Based on that, all of the government institution including public body are required to give transparency information to every information users.

Indonesian National Police is a government institution that has main task in the field of law enforcement, maintaining safety and public order, giving service, protection and shelter the community. Indonesian National Police as a main institution for serving society to apply roadmap of institutional changes contained in blue book "Reform to the professional and independent Indonesian National Police" with the declaration of three fundamental aspects, which is instrumental, structural, and cultural. ${ }^{6}$

Indonesian National Police is curently highlited on all sides, comes from the low level of public trust towards the performance of Indonesian National Police, safety and public order is not created and also the high number of complaints of Indonesian National Police performance. Several cases involving Indonesian National Police become attention for example allegations of cases convict Sun Ang in Medan, fat accounts of senior officer of Indonesian National Police, the suicide of suspect in Polda Metro Jaya, clashes between resident of Binanga and the members of Indonesian National Police in South Tapanuli Resort, etc. Some of that cases must be resolved, without the seriousness in law enforcement, particularly in the enforcement of criminal law, so the violation towards law will

Publik", Jurnal Pranata Hukum, Vol. 6 No. 2, 2011, Lampung: Universitas Bandar Lampung, page 161.

6 Edi Saputra Hasibuan, 2014, Seketsa KOMPOLNAS terhadap Kasus-Kasus Menonjol, Jakarta: Komisi Kepolisian Nasional, page 1. 
continue to occur, and for the next the authority of the state as a rule of law become a bet. According to that condition, if it is allowed to continue there will be mistrust and distrust towards law enforcement and for the law itself in front of public. ${ }^{7}$

Indonesian National Police is also highlighted related to crime clearence information that is the duty of police which is not run optimally. Crime clearence information must be a transparent information where every society can access it easily. Law of Chief of Indonesian National Police No 24 of 2011 concerning Amandement to the Law of Chief of Indonesian National Police No 16 of 2010 about Procedurs Public Information Services in Indonesian Na-tional Police environment (in the next it is called Perkap of Indonesian National Police 24/2011) has been setted about the procedurs related to public information service in police environment, including set the information which one is open and which one is closed for society.

There are various way to deliver public information according Article 29 Perkap of Indonesian National Police 24/2011. First, giving information and data directly; second, accessing information and data through information technology and communication; and third, print and electronic media. A condition when society has trouble to ask public information to police, so the second choice is accessing the information trough information technology media, especially from official website of the police.

Bangkalan Police Resort is one of the 39 police resort and police resort city under East Java Regional Police. Based on that thing, Bangkalan Police Resort is not included in one of 7 police resort in East Java Police area which have no website, however Bangkalan Police resort is included in one of Police Resort that has the latest frequency of information update in the website. According to the condition, delivering public information in Bangkalan Resort is not good, because the obligation to deliver the in-

Ridwan, "Membangun Integritas Penegak Hukum bagi Terciptanya Penegakan Hukum Pidana yang Berwibawa”, Jurnal Media Hukum, Vol 19 No 1 June 2012, Yog yakarta: Universitas Muhammadiyah Yogyakarta, page 89. formation must be done since 2010, but in practice, especially in Bangkalan Police Resort did not run well.

Bangkalan Police Resort is choosen as a place for research because beside of those factors there is other factor, it is because of in the area of Bangkalan Resort there is Faculty of Law of Universitas Trunojoyo Madura as the only partner of the National Police Comission of Republic of Indonesia in East Java, so if there is a partner of the National Police Comission in Bangkalan Police Resort Area will affect the availability of transparency of public information in that area.

\section{Problems}

The problems of this research are: first, Is the information about crime clearance in the area of Bangkalan Police Resort can be accessed by society?; second, what is the concrete correlation between the transparency of imformation about crime clearance with the control of police performance in Bangkalan Police Resort?

\section{Research Methods}

It is a descriptive research - explorative explained about the level of transparency of information about crime clearance in Bangkalan Police Resort as a control to the perfomance of Indonesian National Police by society. Data used is a primary data which is taken directly in research location, area of Bangkalan Police Resort and 17 police sector in area of Bangkalan Resort. Data obtained both quantitative in the form of numbers or data in the form of the result of interview will be analyzed qualitatively using descriptive method that describes and conclude from data taken from place of experiment to get clear picture of crime clearance in the area of Bangkalan Police Resort as a control for Indonesian National Police perfor-mance by society.

\section{Discussion}

Transparency of Public Information in Bangkalan Police Resort Area

A limitation to this research is to examine the transparency of public information about 
the level/numbers of crime clearance in Bangkalan Police Resort Area as a public body. The easiest way to examine the transparency of public information is by seeing the activity of information update through cyberspace or internet. Simply, before the society look for the information related to crime clearance directly to police resort or police sector, the first thing to be searched is official sites of police resort or police sector.

Based on the research result, the latest infomation update of Bangkalan police resort is on July 2011. The site is not the official site but managed in the form of a blog at <http://www. halopolresbangkalan. wordpress.com>, the site is unable to provide information because the content is not up to date (last updated more that four years ago) the content is also can not be justified because it is not managed by the official authority of the Bangkalan Police Resort.

The availability of internet site owned by Bangkalan Police Resort is used as a criteria to determine the transaparency of public information because in Law of Transparency of Public Information and especially in Perkap of Indonesian National Police 24/2011 has been set about the procedure how to deliver public information. Article 7 Law of Transparency of Public Information stated the obligation of public body are: first, public body have to provide, give and/or publish Public Information under their authority to Applicants of Public Information, other than the exempt information based on provisions; second, Public Body have to provide public information that is accurate, thruthful, and not misleading; third, to carry out the obligations stated in paragraph (2), Public Body have to build and develop information system and documentation for managing public information properly and efficiently so that it can be accessed easily; fourth, Public Body have to make written consideration in every taken policy to meet every person's right to Public Information; fifth, the consideration refererred in paragraph (4) such as containing political, economic, social, cultural, and/or defense and nation security consideration; sixth, in order to meet the obligations referred in paragraph (1) until paragraph (4) Public Body can take the advantages from the facilities and/or electronic media and non-electronic.

Based on the above provision, it has been mentioned in number 3, Public Body have to build and develop information system and documentation for managing public information properly and efficiently so it can be accessed easily. Based on the condition in Bangkalan Police Resort, including 17 Police sector under Bangkalan Police Resort, one hundred percent do not have sites, either official or unofficial, so the only way to get information related to police in Bangkalan Area is by searching directly to its place.

This research is focusing on data collection related to the crime clearance in Bangkalan Police Resort Area. The data is one of required data that have to be provided periodically as stated in Article 15 Perkap of Indonesian National Police 24/2011. The information that should be provided are: first, annual working plan report of Indonesian National Police; second, Performance accountability reports of government agencies (LAKIP); and third, statistical data security and public order disturbances every 3 months, 6 months, and anually; fourth, the selection of the candidates for Indonesian National Police including Police Academy (Akpol), Police Officer Resources Bachelor (PPSS), and Brigadier Police of The Republic of Indonesia and fifth, recruitment for Civil Servants (PNS) in Indonesian National Police. Numbers of data of crime clearance in Police is one of information in Performance accountability reports of government agencies, including statistical data security and public order disturbances.

The search results obtained in the search data of criminal clearance in Bangkalan police resort and 17 police sectors underneath; in the sector police of Kamal; Socah; Sukolilo; Arosbaya; Klampis; Sepulu; Tanjungbumi; Tragah; Tanah Merah; Galis; Geger; Blega; Kokop; Modung; Kwanyar; Burneh and Konang are as follows, from 80 of student respondents (as a representation data search team from public), the 47 respondents obtained the data in question 
(data about the settlement in each police sector/police resort) and 33 respon-dents did not get the data, so that the percent-age of successful data retrieval is $59 \%$ of respondents obtain the data and $41 \%$ of respondents did not obtain the data. The reason of police resort or police sector provide the data is not only because of it has official license, but there are some reasons received by police resort or police sector, they are: first, kinship; and second, there is no other reason that can be measured clearly (for example, because the female respondents, respondents polite in asking for the data, etc.). Regarding the reason, police resort/police sector does not provides the data are: first, does not carry permit research/official letters; second, the data is already taken by another respond so it is considered a single entity in the research.

This research has provided significant results in measuring the level of transparency of public information made by the Bangkalan Police resort and 17 Police sector underneath, that is $59 \%$ of respondents obtain the requested data. The data obtained is supposed to be $100 \%$ accessible to the public because the data is an open information that must be provided by the police. Article 9 paragraph (2) The law of Transparency of Public Information said that the information must be published and provided periodically (meaning not need to be asked) are: first, information related to Public Bodies; second, information on the activities and performance of the relevant public bodies; third, information on the financial statements; and/or the fourth, the other information set forth in the legislation.

Added to the text of paragraph (4) which states that the obligation to disseminate public information delivered in a way that is easily accessible by the public and in a language that is easily understood. According to the Article 9 of the Law Transparency of Public Information in conjunction with Article 15 Perkap of Indonesian National Police 24/2011, then the level of transparency of public information in the Bangkalan Police resort can not be said to be good because the information is not generally availa- ble but must be requested, and even then the results obtained do not entirely get the information given.

The Transparency of Public Information as a Control System of Indonesian National Police Performance by Society

Each social development, there is always a desire for the social order. It arise from individual human, but the desire regimentation of someone is not necessarily same to others. Based on that is need a certain threshold through the rule of law. ${ }^{8}$ It is the duty of all society members to obey and carry out the law. Indonesian National Police and the society are two interrelated components, the Indonesian National Police as a representation of the State to ensure the rules of State goes well, while society needs the rule of the State for the ordered life.

Based on the research findings in the field, the level of transparency of public information in the Bangkalan Police Resort can not be said to be good with a variety of indicators as mentioned in the previous section, so that the control system performance of the Indonesian National Police, especially in the Bangkalan Police resort by the society also not going well. The transparency of information about the solved cases number by the Bangkalan Police resort can certainly support the community trust in the performance which conducted by police. This research is comes from the idea of one supervision model which exist in Indonesia within the framework of the criminal justice system is the public involvement in monitoring/control the performance of the law enforcement. Monitoring by the public is the translation of the word control not a translation of the supervision, although both have the same meaning. The meaning of supervision looks spacious because it is not limited to only supervise activities and report the results of supervise activities, but al-

Livia V. Pelle, “Peranan Etika Profesi Hukum terhadap Upaya Penegakan Hukum di Indonesia”, Jurnal Lex Crimen, Vol. I No. 3 2012, Manado: Universitas Sam Ratulangi, page 27. 
so perform control activities that move, repair and straighten to the right direction. ${ }^{9}$

One form of the simplest public involvement is the convenience of public in accessing information related to the settlement that has been done by the police, in this case is the Bangkalan Police resort and 17 police sectors underneath. Public is one of the factors that affect the enforcement of the law itself, because law enforcement derived from the public and aim to achieve a peace in public. Legal awareness of public in this case is important, the higher of legal public awareness is make better for law enforcement, otherwise the lower level of legal public awareness is more difficult to carry out a good law enforcement. ${ }^{10}$ Awareness of the legal society will be assessed in the viewpoint criminological theory, one of that is the theory of social control.

Travis Hirschi said that there are four social bonds that encourage socialization and conformity, that is: attachment, commitment, involvement and belief. ${ }^{11}$ That social bond will be described one by one the relationship of pulic involvement as a form of monitoring the performance of the Indonesian National Police in the Bangkalan Police resort and police sectors underneath.

First, attachment is the human ability to involve itself to others, including the environment. The involvement of public to involved itself as one of the mechanisms for performance monitoring system of the Indonesian Police certainly will support the performance of the Indonesian National Police. The existence of partners National Police Commission in the Faculty of Law, Universitas Trunojoyo Madura should open the door widely for society involvement as

Nurmin K. Martam, "Urgensi Keberadaan Komisi Pengawasan Kepolisian Ditinjau dari Hukum Administrasi Negara", Jurnal Legalitas, Vol. 2 No. 3 2009, Gorontalo: Universitas Negeri Gorontalo, page 57.

10 Ediwarman, "Paradoks Penegakan Hukum Pidana dalam Perspektif Kriminologi di Indonesia", Jurnal Kriminologi Indonesia, Vol. 8 No. 1 Mei, 2012, Jakarta: Universitas Indonesia, page 45

11 Tolib Effendi, "Kajian Kriminologis terhadap Fenomena Premanisme dan Geng Motor", Jurnal Rechtldee, Vol. 7 No. 2, 2012, Bangkalan: Universitas Trunojoyo Madura, page 10 . control system performance of the Indonesian National Police. Universities can involving students as one of the agents who can receive Suggestion and Public Complaints on the performance of the Indonesian National Police as performance of the Indonesian Police control system. Students can also be involved directly with the data of crime clearance in the Indonesian National Police to control the performance of the Indonesian National Police in the criminal clearance. But so far, the role of society has not been optimal in utilizing colleges as partner of the National Police Commission to supervise performance of Indonesian National Police. Since Faculty of Law University Trunojoyo Madura joined as a partner of the National Police Commission in March 2015, none Suggestion and Complaints Society delivered.

Second, commitment or entanglement in a conventional subsystems. Commitment is the attachment of someone on the sub conventional systems such as the environment, employment and so forth. The public can becoming a pioneer in monitoring performance of Indonesian National Police and vice versa, Indonesian National Police has a commitment to unsolicited reports the performance periodically with the publication of the information system that is easily accessible by the public. The information system that is easily accessible by the society. This commitment has not gone well in both directions, meaning that both the community and Indonesian National Police in the Police Bangkalan resort has not the same commitment to be involved in the monitoring and to report on performance of the publication that is easy to access by the public.

Third, involvement or active function in conventional subsystems. Both society and the police of the Republic of Indonesia are actively involved in performance of the law enforcement system bacause both of them are component in the system of law enforcement. The existence of active involvement between the two components of law enforcement will minimize irregularities in law enforcement. Actually involvement of people represented by the students who participated actively to asking the informa- 
tion about developments related to the case of each semester as one of the subjects as the assignement in the faculty can be considered as active involvement in order to supervise performance of Indonesian National Police in the region of Bangkalan.

Fourth, beliefs, or believe in the moral values of the norms and values of social life. Beliefs is different with other elements before, because beliefs are the moral aspect which contained on the social bond, beliefs is a person's belief in the moral values that exist. Cultivating the trust becomes a different challenge for Indonesian National Police, the society had a less good view on performance of Indonesian National Police and Indonesia National Police is trying to change the bad image society. The supervisory system will not be able to run maximumly if society conduct monitoring did not based on trust, but by the spirit to look for errors and correct the performance of Indonesian National Police.

Monitoring by the society if it is associated with the transparency of public information as one of the criteria, indicating the involvement of society who play an active role to monitor and control the performance of the police in line with the commitment of the police to report on the work which has been done either periodically or when people need information which not including the exempted information.

Among all, the existence of belief or public confidence in the police performance will be more improved the involvement between the society and the police and vice versa. The public's distrust is always started from the performance is not well, or at least not well controlled. The transparency of good performance, so the people can know the constraints faced by the police so that the community can provide a support for their active community involvement as one of the components of law enforcement.

\section{Conclusion}

This research has two conclusions, they are: first, the level of transparency of public information in the Bangkalan Police resort can not said to be good because the information is not generally available but must be requested, and even then the results are not entirely get the information given. Bangkalan Police resort and 17 other sector police under it has not been having an information system that publicly accessible by the public, while the society want to get information directly it can not be served well, even though the requested information does not include information which excluded.

Second, transparency of information in the Indonesian National Police is expected to be the performance of control system Indonesian National Police by the society. Conditions in the Region of Bangkalan Police resort the transparency of information in the body of Indonesia National Police can not be good so that the control system performance of it can not run well too. Besides the lack of exposure factor information in the body of Indonesian National Police, public participation in the monitoring system also can not be run maximumly. Some indicators of a lack society involvement is still weak attachment, commitment, involvement and belief of the community, including from the Indonesian National Police itself to be able to create a good law enforcement. Among all, the existence of public confidence in the police performance will be more improve the attachment between the public and the police and vice versa. Distrust is always started from the performance is not good, or at least not well controlled. Transparency good performance, so that public can find out constraints faced by the police so that the public can provide a support for their active community involvement as one of the components of law enforcement.

\section{Suggestion}

Suggestions are given on the results of this study is, transparency of information to public is an obligation that must be carried out by the Bangkalan Police resort and 17 police sector underneath. One form of transparency of information is information system which can be accessed by the general public widely and easily and also recency and frequency of data or news related to activities in the police force must be maintained. Transparency of public information 
is also to cultivate attachment between society and police to monitoring run well so that the law enforcement process can run smoothly and more society feel protected by the presence of the police which one of its functions is to provide protection to the public.

\section{References}

Ediwarman. "Paradoks Penegakan Hukum Pidana dalam Perspektif Kriminologi di Indonesia". Jurnal Kriminologi Indonesia, Vol. 8 No. 1 Mei, 2012. Jakarta: Universitas Indonesia;

Effendi, Tolib. "Kajian Kriminologis terhadap Fenomena Premanisme dan Geng Motor". Jurnal Rechtldee, Vol 7 No. 2, 2012. Bangkalan: Universitas Trunojoyo Madura;

Fauzin. "Keberpihakan Pengaturan Hak Atas Informasi Publik dalam Undang-Undang Keterbukaan Informasi Publik". Jurnal Pranata Hukum, Vol. 6 No. 2 2011. Lampung: Universitas Bandar Lampung;

Hasibuan, Edi Saputra. 2014. Seketsa KOMPOLNAS terhadap Kasus-Kasus Menonjol. Jakarta: Komisi Kepolisian Nasional;

Martam, Nurmin K. "Urgensi Keberadaan Komisi Pengawasan Kepolisian Ditinjau dari Hukum Administrasi Negara". Jurnal Legalitas, Vol 2 No. 3 2009. Gorontalo Universitas Negeri Gorontalo;

Pelle, Livia V. "Peranan Etika Profesi Hukum terhadap Upaya Penegakan Hukum di Indonesia". Jurnal Lex Crimen, Vol. I No. 3 2012. Manado: Universitas Sam Ratulangi;

Ramadhan, Choky and Aulia Ali Reza. 2015. Keterbukaan Informasi Kejaksaan: Implementasi dan Permasalahan, in Bunga Rampai Kejaksaan Republik Indonesia, Jakarta: Badan Penerbit Faculty of Law UI;

Ramiyanto. "Sah atau Tidaknya Penetapan Tersangka sebagai Objek Gugatan Praperadilan: Kajian Putusan Nomor 04/Pid.Prap/ 2015/PN.Jkt.Sel”. Jurnal Yudisial, Vol. 8 No. 2 Agustus 2015. Jakarta: Komisi Yudisial;

Ridwan. "Membangun Integritas Penegak Hukum bagi Terciptanya Penegakan Hukum Pidana yang Berwibawa". Jurnal Media Hukum, Vol. 19 No. 1 Juni 2012. Yogyakarta: Universitas Muhammadiyah Yogyakarta;

Sumrahyadi and Erwan Baharudin. "Antropologi Hukum dalam Implikasi Undang-Undang
Keterbukaan Informasi Publik". Jurnal Lex Jurnalica, Vol 6 No. 2 April 2009. Universitas Esa Unggul, Jakarta;

Susanto, Eko Harry. "Undang-Undang Keterbukaan Informasi Publik dan Penyelenggaraan Pemerintahan". Jurnal Komunikator, Vol. 5 No. 3, 2013. Yogyakarta: Universitas Muhammadiyah Yogyakarta. 